\title{
Molecular forms of phosphatase and ribonuclease in phosphate deficient and N,N-dimethylmorpholinium chloride treated Spirodela oligorrhiza (Lemnaceae)
}

\author{
J. S. KNYPL \\ Plant Growth Substances Laboratory, University of Łódź \\ (Received: August 25, 1978)
}

\begin{abstract}
Soluble, membrane bound, and extracellular phosphatases (EC 3.1.3.2 and 3.1.3.1) of control, N,N-dimethylmorpholinium chloride (DMMC) treated, and phosphate deficient (-P) axenic Spirodela oligorrhiza plants were analysed by Sephadex G-150 gel filtration. Soluble, acid enzymes of control plants were separated into two molecular forms with apparent $\mathrm{MW} \geqslant 400000$ and 85000 . Phosphatase with MW 34000 replaced the latter isoenzyme in the presence of DMMC. Two alkaline enzymes with apparent MW 210000 and 36000 were detected in $-\mathrm{P}$ plants.

Triton X-100 solubilized a number of acid and alkaline phosphatases from membrane material. DMMC caused the appearance of two membrane bound enzymes (MW 48000 and 14000) which were not detected in the control. Senescing control and DMMC treated plants released an acid phosphatase (MW $48000 ; \mathrm{pH}$ optimum 5.2) into the nutrient medium. -P plants released, in addition , an alkaline phosphatase ( $\mathrm{MW} 170,000 ; \mathrm{pH}$ optimum 7.8-8.2). Ribonucleases (EC 2.7.7.17.) with apparent MW 31000 and 28000 daltons were induced by DMMC and $-\mathrm{P}$, respectively.
\end{abstract}

\section{INTRODUCTION}

Unspecific acid phosphatase (orthophosphoric monoester phosphohydrolase, EC 3.1.3.2) is ubiquitous in plants. The enzyme is heterogenous upon chromatography and electrophoresis (B a il e y et al. 1976, F'oster and Weber 1973; Kubicz et al. 1972; Lorens-Kubis et al. 1975; Rychter et al. 1972; Murray and Collier 1977; Papageorgakopoulou and Georgatsos 1977). Total activity

Abbreviation used: DMMC, N,N-dimethylmorpholinium chloride; NPP, p-nitrophenylphosphate; $-\mathrm{P}$, phosphate deficiency; $\mathrm{M}$, nutrient medium; $\mathrm{MB}$ and $\mathrm{S}$, membrane bound and soluble enzymes; Ac, acid; Alk, alkaline. 
of this enzyme markedly increases in plants grown in conditions of mineral deficiency (H e wit 1958; $\mathrm{Hew}$ it t and $\mathrm{T}$ a tham 1960). Some micronutrients, e.g. zinc, may decrease the phosphatase activity in plants ( $\mathrm{Cox}$ and Thurman 1978).

Soluble phosphatase of Spirodela oligorrhiza (Kurz) Hegelmaier, a small aquatic plant of the family Lemnaceae ( $\mathrm{McCl}$ u re and A 1 s t on 1966), has pH optimum 5.7-6.0 (B i e le s k i 1974) and it exists in two molecular forms ( $\mathrm{Knypl} 1976$ ). In a response to phosphate deficiency two isoenzymes of alkaline phosphatase (EC 3.1.3.1) are synthesized (Reid and Bieleski 1970a; Bieleski 1974). These derepressible enzymes have a $\mathrm{pH}$ optimum at 7.5 , and their relative activity prevails manyfold over the activity of a constitutive acid enzyme. The alkaline enzyme is not released into the nutrient medium (B i e leski 1974). Nevertheless, around $40 \%$ of the alkaline phosphatase activity appears to be available to phosphate esters in the external medium, i.e. the enzymes seem to be localised externally on the outer surface of the cells (Bieleski 1974), possibly in the plasmalemma (Knypl and Sobolewska 1978). There are evidences that both acid and alkaline phosphatase activity is released by the plants to the external medium in some "special" conditions (K n y pl 1976b).

It has recently been reported that $\mathrm{N}, \mathrm{N}$-dimethylmorpholinium chloride (DMMC), a plant growth retardant ( $\mathrm{Kny} \mathrm{pl}$ et al. 1976), increased total phosphatase activity in Spirodela, and that phosphate deficiency caused the release of some phosphatase activity into the nutrient medium (K nypl 1977). A considerable phosphatase activity was also detected in tissue debris remaining upon the extraction of the soluble enzymes; this residual activity was particularly marked in senescing and $-\mathrm{P}$ plants (K n y pl and $\mathrm{Kabzinska1977).} \mathrm{This} \mathrm{fact} \mathrm{seems} \mathrm{to} \mathrm{indicate} \mathrm{that} \mathrm{in}$ Spirodela a proportion of phosphatase activity is associated with the cell membranes (Kny pl and Sobolewska 1978), as it is in other plants (Hirai and A sahi 1973; Willi a m s and J u o 1976). The aim of this study was to analyse multiple forms of soluble, membrane bound and extracellular phosphatases in the control, DMMC treated and phosphate deficient Spirodela cultures. Since $-\mathrm{P}$ and treatments with DMMC induce high RNase activity (Reid and Bieleski 1970a; Knypl $1976 \mathrm{~b} ; \mathrm{K} \mathrm{n} \mathrm{y} \mathrm{pl} \mathrm{and} \mathrm{K} \mathrm{a} \mathrm{bzińska} \mathrm{1977),} \mathrm{analyses} \mathrm{of} \mathrm{this} \mathrm{enzyme} \mathrm{were}$ also performed.

MATERIAL AND METHODS

Plants

Axenic Spirodela oligorrhiza (Kurz) Hegelm. was grown according to Bollard (1966) under continuous illumination $(1.5 \mathrm{Klx})$ produced by fluorescent tubes (Flora LF40W, Unitra-Polam) at $25^{\circ} \mathrm{C}$ in Roux 
bottles containing $200 \mathrm{ml}$ of nutrient media. The control nutrient medium (C) contained 1.0\% glucose, macro- and microelements, and $5 \mathrm{mM}$ ammonium sulphate as sole $\mathrm{N}$ source (Knypl 1976a). This medium was supplemented with $0.4 \mathrm{mM}$ of filter sterilized DMMC (DMMC-treated plants) or deprived of orthophosphate (-P plants). In the latter case $\mathrm{K}_{2} \mathrm{HPO}_{4}(1 \mathrm{mM})$ was replaced by $\mathrm{K}_{2} \mathrm{SO}_{4}$. The nutrient media were buffered with solid sterile $\mathrm{CaCO}_{3}$ added after autoclaving (B ollard 1966), then inoculated with ca. 70 fronds (control series) or 200-400 fronds (DMMC and $-\mathrm{P}$ series). For analyses of extracellular phosphatase in the $-\mathrm{P}$ plants, the plants were grown in $100 \mathrm{ml}$ conical flasks containing $30 \mathrm{ml}$ of the $-\mathrm{P}$ nutrient medium.

Doubling time for the control plants was $44 \mathrm{~h}$. DMMC and $-\mathrm{P}$ decreased the growth rate of the plants, producing typical morphological symptoms that already have been described ( $\mathrm{K}$ y pl et al. 1976 ; $\mathrm{R}$ e id and Bieleski 1970b).

\section{Extraction of enzymes}

All extractions were performed at $0-4^{\circ} \mathrm{C}$. $0.05 \mathrm{M}$ Tris- $\mathrm{HCl}$ buffer, $\mathrm{pH} 7.4$ (as measured at $20^{\circ} \mathrm{C}$ ) was used, if not otherwise stated.

Soluble phosphatase. Plants were washed with distilled water, blotted dry, frozen in liquid nitrogen and ground in a mortar and pestle with hydrated Polyclar AT (2 g PVP per $\mathrm{g}$ fr wt of tissue) and Tris- $\mathrm{HCl}$, buffer $(4 \mathrm{ml}$ per $\mathrm{g}$ fr $\mathrm{wt}$ ). Tissue debris remaining after centrifugation at $3500 \mathrm{~g}$ for $20 \mathrm{~min}$ was extracted twice with this buffer $(2 \mathrm{ml}$ per $\mathrm{g}$ original fr wt; each extraction time $20 \mathrm{~min}$ ). Pooled supernatant fractions were passed through 4 layers of Miracloth, then centrifuged at $15000 \mathrm{~g}$ for $20 \mathrm{~min}$ and concentrated twice by passing through dry Sephadex G-25 in a bench centrifuge (800 g for $10 \mathrm{~min}$; cf. Kohl 1969). The resulting extract contained crude soluble enzyme.

Membrane bound phosphatase. Tissue debris remaining after extraction of soluble fraction was gently stirred with $0.05 \mathrm{M}$. Tris- $\mathrm{HCl}$ buffer, $\mathrm{pH} 7.4$, supplemented with $0.5 \%$ Triton X-100 (cf. Williams and Juo 1976 ) for $30 \mathrm{~min}$ and cleared by centrifugation. The pellet was again agitated with the same buffered solution of the detergent, and centrifuged. Combined supernatants $(3 \mathrm{ml}$ per g original tissue $\mathrm{fr} w \mathrm{t})$ were precipitated with $70 \%$ acetone $\left(-21^{\circ} \mathrm{C}, 30 \mathrm{~min}\right)$ and solubilized in 0.05 M Tris- $\mathrm{HCl}$ buffer without Triton X-100. Insoluble material was discarded and the supernatant fraction concentrated twice with dry Sephadex G-25. The final extract contained "membrane bound" phosphatase activity. The term "membrane bound" means that the enzyme activity could not be solubilized with the buffer alone. None tests have been performed to determine the in situ localization of this enzyme activity. 
Extracellular phosphatase. $\mathrm{CaCO}_{3}$ from nutrient media remaining after culture the plants was discarded by sedimentation. Chilled acetone $\left(-21^{\circ} \mathrm{C}\right)$ was added to a final concentration of $70 \%$, and the precipitatie formed during standing for $30 \mathrm{~min}$ at $-21^{\circ} \mathrm{C}$ sedimented at $3500 \mathrm{~g}$ (10 min). The pellet was extracted twice with Tris- $\mathrm{HCl}$ buffer $(1 \mathrm{ml}$ per $10 \mathrm{ml}$ of original nutrient medium) by continuous shaking for $30 \mathrm{~min}$, and insoluble salts discarded by centrifugation. The supernatant fraction was concentrated by means of dry Sephadex G-25 as described.

Soluble, membrane bound and extracellular phosphatases were extracted from the same culture of a given type (C, DMMC or $-\mathrm{P}$ ) with some exceptions. MB phosphatase activity in the control 12-day old plants was too low to be analysed by gel chromatography, and this enzyme fraction was extracted from 2 days older culture. For the same reason the extracellular phosphatase was extracted from a nutrient medium of senescent 25-day old control plants.

Gel chromatography

$2.6 \times 90 \mathrm{~cm}$ bed of Sephadex G-150 (column K-26/100, Pharmacia AG, Uppsala, Sweden) was equilibrated with $0.05 \mathrm{M}$ Tris- $\mathrm{HCl}$ buffer, $\mathrm{pH}$ 7.4, and calibrated with protein standards of known MW: cytochrome C, MW 12400 (Polfa); RNase A, MW 13700 (Koch-Light Laboratories, Ltd.); horseradish peroxidase, MW 40000 (Koch-Light Laboratories, Ltd.); ovoalbumin, MW 45000 (Serva Feinbiochemica); human serum $\gamma$-globulin, fraction II, MW 160000 (Calbiochem); ferritin, MW 480000 (Serva Feinbiochemica); and dextran blue 2000, MW 2000000 (Pharmacia AG). Enzymes applied to the column in a volume of 2 to $5 \mathrm{ml}$ were eluted with downward flow of $0.05 \mathrm{M}$ Tris- $\mathrm{HCl}$ buffer, $\mathrm{pH}$ 7.4. $5 \mathrm{ml}$ fractions were collected each $15 \mathrm{~min}$.

Ten gramms of DEAE-Sephadex A-25 which had been swollen in $0.05 \mathrm{M}$ Tris- $\mathrm{HCl}$ buffer, $\mathrm{pH}$ 7.4, was poured into a column and pressed to form a bed of $2.6 \times 10 \mathrm{~cm}$. Combined eluates from Sephadex G-150 chromatography, comprising peaks of phosphatase and/or RNase activity, were applied to the column (usually in a volume of $30 \mathrm{ml}$ ), washed with Tris- $\mathrm{HCl}$ buffer, and eluted with a linear gradient of $0-0.4 \mathrm{M} \mathrm{NaCl}$ in the same buffer. $5 \mathrm{ml}$ fractions were collected.

Chromatography was performed at $4-8^{\circ} \mathrm{C}$.

Enzyme assays

Phosphatase and ribonuclease activities were assayed essentially as described by Kny pl (1977). 
RNase (EC 2.7.7.17). $0.1 \mathrm{ml}$ of highly polymerized yeast RNA was mixed with $0.1 \mathrm{ml}$ of $0.1 \mathrm{M}$ citrate buffer ( $\mathrm{pH} 6.0$ ), and $0.1 \mathrm{ml}$ of eluate from a column. Reaction was allowed to proceed for $60 \mathrm{~min}$ at $30^{\circ} \mathrm{C}$, then stopped by adding $3.0 \mathrm{ml}$ of magnesium-lanthanum precipitating reagent (A mbella n and $\mathrm{Hollander} \mathrm{1966).} \mathrm{Absorbance} \mathrm{at} 260 \mathrm{~nm}$ was read, and values of A $260 \mathrm{~nm}$ corrected for 11-fold dilution with the precipitating reagent and for $t_{o}$ blanks into which enzyme was added after the precipitating reagent. RNase activity is expressed as $\triangle \mathrm{A}_{260} \mathrm{~nm}(0.1 \mathrm{ml} \text { eluate })^{-1}$ per equivalent of $\mathrm{g}$ fr wt applied to the column of Sephadex G-150.

Phosphatase (EC 3.1.3.1. and 3.1.3.2). $8 \mathrm{mM}$ p-nitrophenylphosphate in glycine-maleate-Tris-citrate buffer (Bieleski 1974; Knypl and, Sobolewska 1978) was used as a substrate for phosphatase assays at $\mathrm{pH} 5,6$ and 7.5 (as measured in a whole assay mixture at $30^{\circ} \mathrm{C}$ ). The assay mixture contained $0.1,0.2$ or $0.5 \mathrm{ml}$ eluate in a final volume of $1.5 \mathrm{ml}$. The reaction was allowed to proceed for $20 \mathrm{~min}$ at $30^{\circ} \mathrm{C}$, and stopped by adding $1.0 \mathrm{ml}$ of $0.3 \mathrm{~N} \mathrm{NaOH}$. Absorbance at $404 \mathrm{~nm}$ was read and corrected for $t_{0}$ blanks into which $\mathrm{NaOH}$ solution was added before the eluatie. The phosphatase activity, unless otherwise stated, is expressed as $\Delta \mathrm{A}_{404} \mathrm{~nm}(0.5 \mathrm{ml} \text { eluate })^{-1}$ per an equivalent of $\mathrm{g}$ fr wt of tissue applied to a column, or per such a volume of nutrient medium which was equivalent to $1 \mathrm{~g}$ of floating plants at the very time of analyses. Phosphatase activity in crude nutrient media is expressed as $\triangle \mathrm{A}_{404} \mathrm{~nm}(0.2 \mathrm{ml} \mathrm{medium})^{-1}$. Unit (U) of phosphatase activity in crude extracts is defined as the amount of enzyme which releases one $\mu$ mole of $p$-nitrophenol $\mathrm{min}^{-1} \mathrm{~g}^{-1} \mathrm{fr}$ wt.

$\mathrm{K}_{\mathrm{m}}$ of extracellular phosphatases towards NPP was estimated according to Eisenthal and Cornish-Bowden (1974).

Highly polymerized yeast RNA and NPP were purchased from POCh (Gliwice) and E. Merck (Darmstadt), respectively. DMMC was kindly synthesized by Dr. Małgorzata Oświęcimska (The Technical University, Wrocław).

\section{RESULTS}

Soluble phosphatase and RNase

Two molecular forms of soluble phosphatase were detected in extracts of control plants which had been taken for analyses at the end of a log phase of growth. One of these enzymes, subsequently denoted CS-I, was eluted in a void volume of the Sephadex G-150 column. Its MW is equivalent to or higher than 400000 , since exclusion limit for 
this type of Sephadex is 400000 . Second molecular form of the enzyme, CS-II, was eluted as a broad peak (Fig. 1). Its apparent MW is around 85 000. CS-I and CS-II had a $\mathrm{pH}$ optimum at 5.8-6.0.

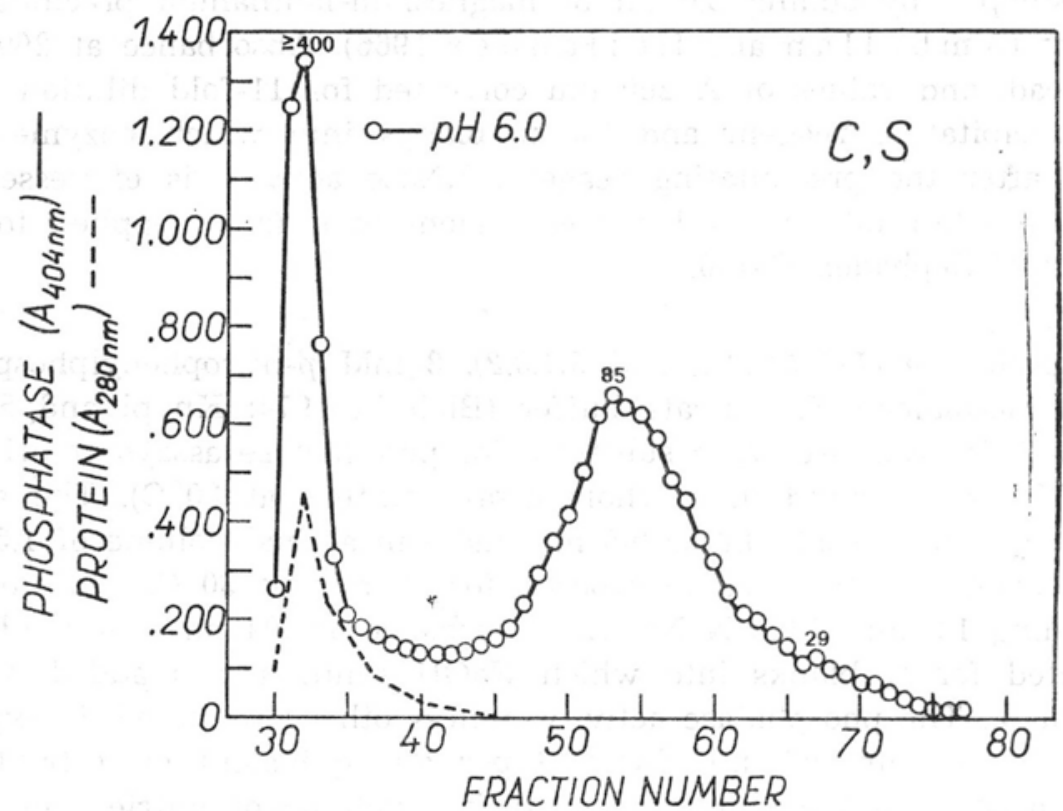

Fig. 1. Elution profile of soluble phosphatases of control plants. Phosphatase was extracted from 12-day old plants $\left(1.2 \mathrm{U} \mathrm{g}^{-1} \mathrm{fr} w \mathrm{t}\right) ; 80 \%$ of applied activity recovered from a columns of Sephadex G-150. Enzyme activity is expressed as $\Delta \mathrm{A}_{404} \mathrm{~nm}$ $(0.5 \mathrm{ml} \text { eluate })^{-1}(20 \mathrm{~min})^{-1}$ per equivalent of $1 \mathrm{~g} \mathrm{fr}$ wt. Numbers above peaks of enzyme activity in this Fig. and all others mean $\mathrm{MW} \times 10^{-\mathbf{3}}$.

Pooled fractions containing CS-I and CS-II were rechromatographed on DEAE-Sephadex A-25. CS-I proved to be heterogenous (Fig. 2a). Around a one third of the total enzyme activity was eluted with the washing buffer. The $\mathrm{K}_{\mathrm{m}}$ of this fraction towards NPP as a substrate is $0.25 \mathrm{mM}$. The remaining part of enzyme activity was recovered upon elution with a $\mathrm{NaCl}$ gradient (peak of enzyme activity at $0.14 \mathrm{M} \mathrm{NaCl}$, Fig. 2). Discrete shoulders suggest that a number of isoenzymes are present in that portion of CS-I which binds to the anion exchange gel.

Almost total CS-II was eluted with washing buffer (Fig. 2b). However, a minor proportion of enzyme activity was bound to DEAE-Sephadex and eluted with $\mathrm{NaCl}$. This small peak appeared again when the first peak of phosphatase activity was pooled and rechromatographed after one day of storage at $0^{\circ} \mathrm{C}$. Thus, the enzyme present in this small peak is obviously formed upon the storage of the extracts. This minor fraction is "more acid" than the other one, as values of an equation: activity at $\mathrm{pH} 6$ to activity at $\mathrm{pH} 7.5$, were 1.20 and 1.70 for the fractions eluting with washing buffer and buffered $\mathrm{NaCl}$ solution, respectively. 


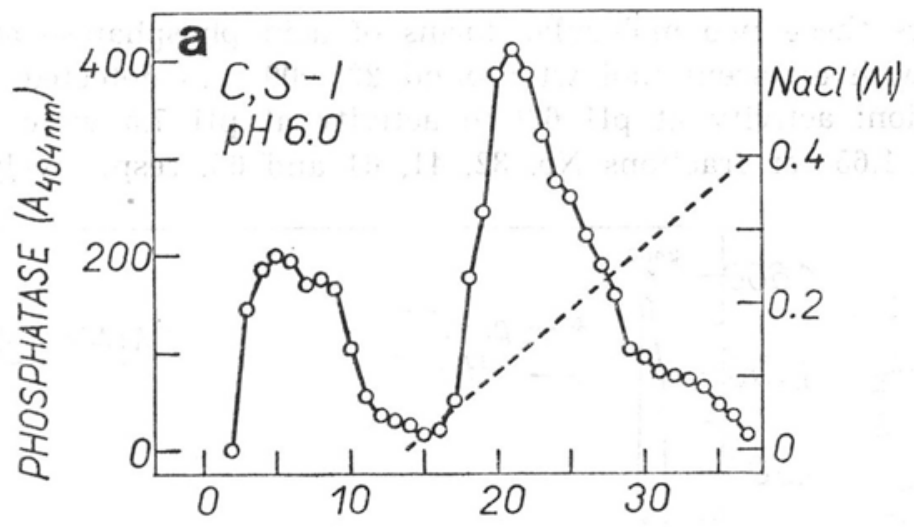

FRACTION NUMBER

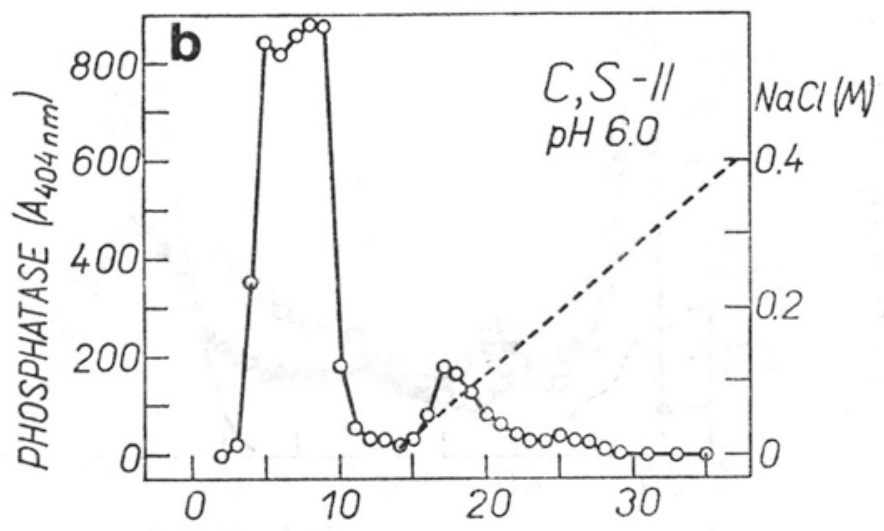

FRACTION NUMBER

Fig. 2. Fractionation of CS-I and CS-II isoenzymes on DEAE-Sephadex A-25. Source of CS-I and CS-II: fractions No. $30-40$ and $47-61$ of Fig. 1, respectively $90 \%$ of applied activity was recovered.

Ribonuclease was present in extracts prepared from the control plants (Kny pl 1977) but its activity was too low to be detected in eluates from the column of Sephadex G-150.

The optimum of phosphatase activity in crude extracts of the DMMC treated plants was at $\mathrm{pH}$ 6.0-6.3, whereas in the control maximum activity was at $\mathrm{pH}$ 5.8-6.0. There was present a high mol wt phosphatase DMMC,S-I. The presence of isoenzyme corresponding to CS-II was manifested by a very minor peak (Fig. 3, tubes No. 51-52). CS-II was replaced by a very remarkable isoenzyme denoted DMMC,S-II with a molecular weight of around 34000 . Peak of activity of this enzyme was constantly saddle-shaped as if it comprised two components with apparent MW of ca. 32000 (alkaline) and 36000 (acid). Phosphatase DMMC,S-II was eluted together with a high RNase activity (MW $31000 ; \mathrm{pH}$ optimum 5.2). 
Besides these two molecular forms of acid phosphatase an alkaline enzyme with apparent mol wt around 220000 was detected. Values of an equation: activity at $\mathrm{pH} 6.0$ to activity at $\mathrm{pH} 7.5$ were $1.59,0.66$, 2.15, and 1.65 for fractions No. 32, 41, 61 and 66, respectively (Fig. 3).

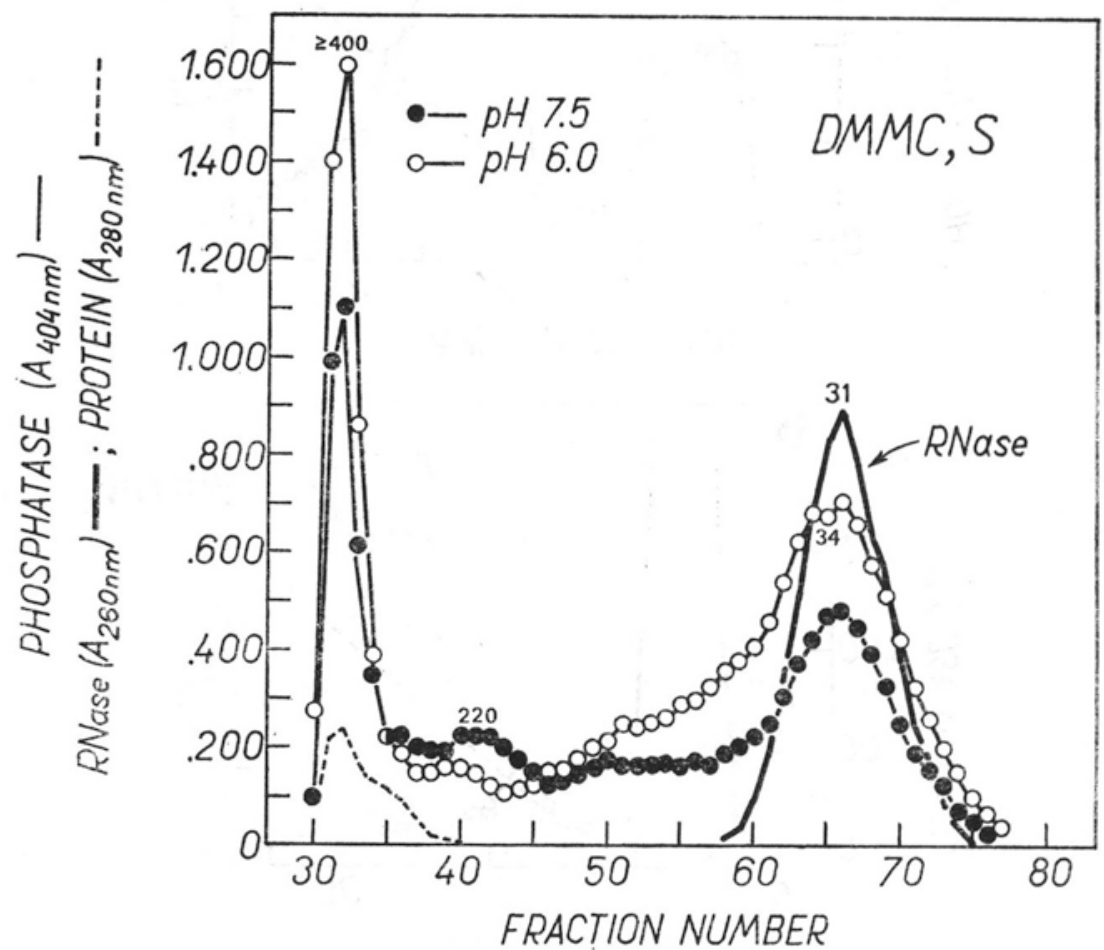

Fig. 3. Elution profile of soluble phosphatase and RNase of DMMC treated plants. The plants were grown in $0.4 \mathrm{mM}$ DMMC for 9 days.

Elution profile of DMMC,S-I from DEAE-Sephadex was similar to that of CS-I (data not shown). Also elution profile of DMMC, S-II was similar to that of CS-II except that a third minor peak of enzyme activity eluting with $0.16-0.17 \mathrm{M} \mathrm{NaCl}$ appeared (Fig. 4).

DMMC-treated plants showed 20- to 50-fold higher RNase activity in comparison with the control plants (Kny pl 1976b, 1977). All the DMMC enhanced RNase activity was bound to DEAE-Sephadex and major portion of the activity eluted with $0.12 \mathrm{M} \mathrm{NaCl}$ (Fig. 4). Chromatography on DEAE-Sephadex A-25 can, thus, be used for separating RNase activity from phosphatase activity in extracts of soluble enzymes of the DMMC treated Spirodela oligorrhiza.

Crude extracts of soluble phosphatase from Spirodela which had been grown for 17 days in $-\mathrm{P}$ nutrient medium showed $6.00,4.14$, and 4.08 $\mathrm{U}^{\mathrm{g}^{-1}}$ fr wt at $\mathrm{pH} 7.5,6.0$ and 5.0, respectively. Chromatography on Sephadex G-150 revealed the presence of three phosphatase isoenzymes, 


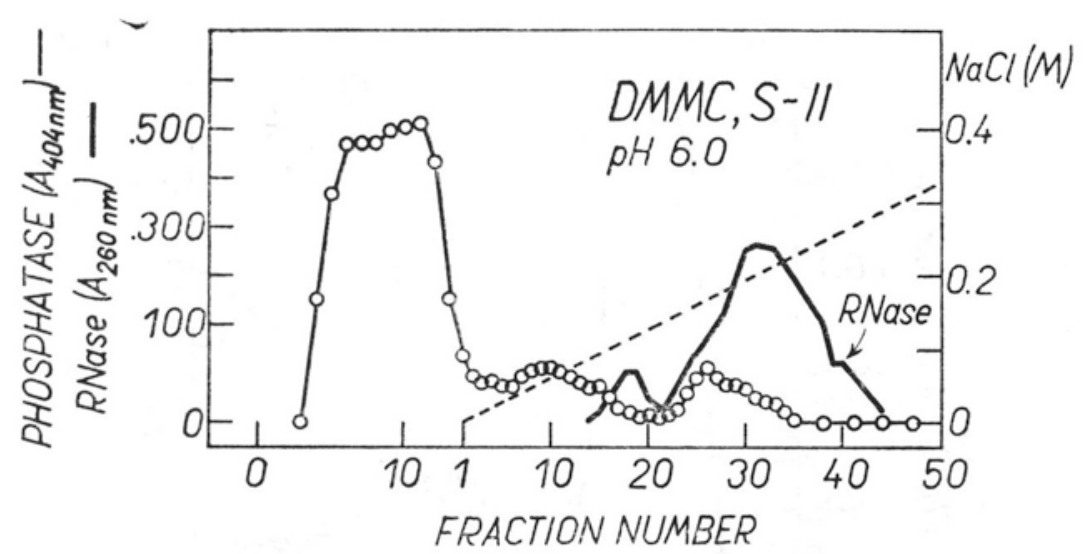

Fig. 4. Fractionation of DMMC,S-II isoenzyme on DEAE-Sephadex A-25. 90\% of applied activity (Fig. 3, fractions No. 61-71) was recovered.

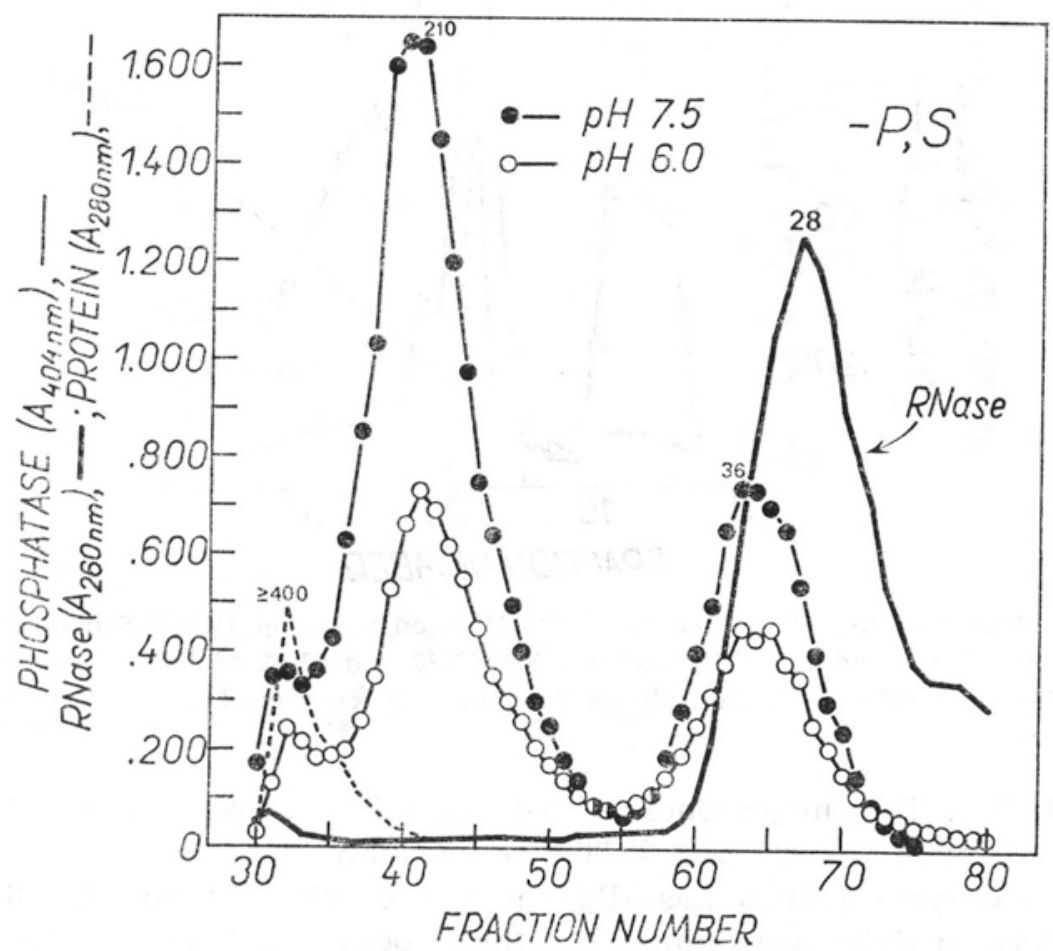

Fig. 5. Elution profile of soluble phosphatases and RNase of $-\mathrm{P}$ plants. Plants were grown for 17 days on $-\mathrm{P}$ nutrient medium yielding $3.5 \mathrm{fr}$ wt per bottle; total soluble enzyme activity: 6.00 and $4.10 \mathrm{U} \mathrm{g}^{-1} \mathrm{fr}$ wt at $\mathrm{pH} 7.5$ and $\mathrm{pH} 6.0$, respectively. $102 \%$ of applied activity was recovered from a column of Sephadex G-150. Enzyme activity in this Figure, in contrast to all others, is expressed per $0.1 \mathrm{ml}$ eluate. RNase activity: $\Delta \mathrm{A}_{260} \mathrm{~nm} \mathrm{\textrm {h } ^ { - 1 }}(0.1 \mathrm{ml} \text { eluate })^{-1}$. 

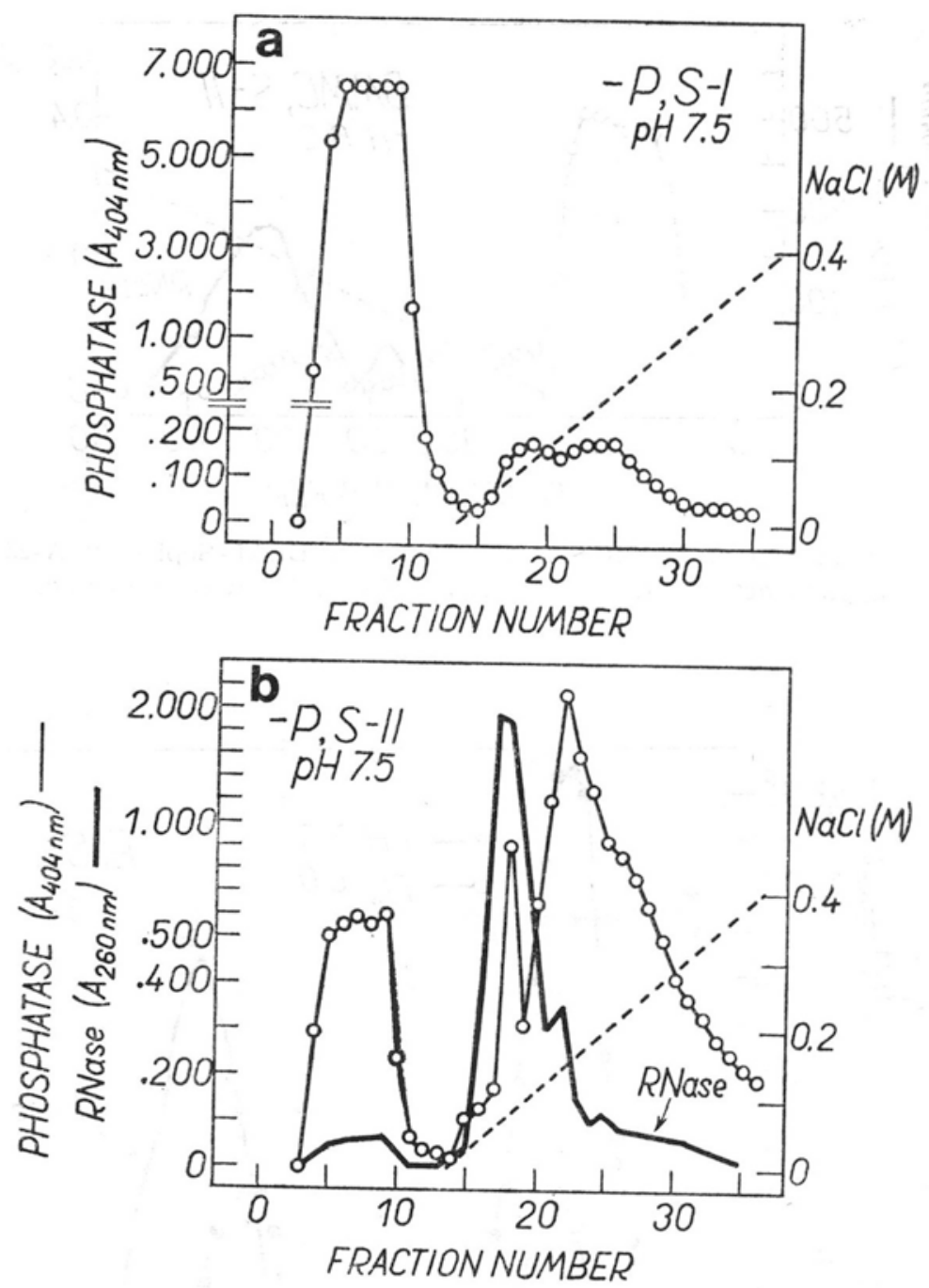

Fig. 6. Fractionation of -PS-1 and -PS-II isoenzymes on DEAE-Sephadex A-25. Source of -PS-I and -PS-II: fractions No. 36-48 and 67-72 of Fig. 5, respectively. $104 \%$ and $96 \%$ of applied phosphatase activity recovered in the eluates.

all alkaline. Two major ones, -PS-I and -PS-II, are characterized by mol wt around 210000 and 36000 , respectively. Third relatively minor peak of enzyme activity has MW equal to or higher than 400000 (Fig. 5). RNase activity was eluted in three peaks. Mol wt of the main RNase fraction was estimated for 28000 daltons (Fig. 5, fraction No. 67).

The main $-\mathrm{P}$ soluble phosphatases eluted from a column of Sephadex G-150 differ in respect to activity at $\mathrm{pH} 7.5$ and $\mathrm{pH} 6.0$. Values of an equation: activity at $\mathrm{pH} 7.5$ to activity at $\mathrm{pH} 6.0$ were $1.67,0.65$, and 
1.33 for fractions No. 40 (-PS-I), 55, and 65 (-PS-II), respectively (Fig. 5).

Almost total phosphatase -PS-I was not bound to DEAE-Sephadex A-25, but a minor fraction representing ca. $5 \%$ of total recovered activity was eluted with 0.14 and $0.18 \mathrm{M} \mathrm{NaCl}$ (Fig. 6a). This minor fraction of enzyme activity appeared again when the first peak of phosphatase activity was pooled and rechromatographed. It is, thus, formed upon storage of the eluates.

Low molecular weight phosphatase -PS-II was heterogenous. Of three distinct fractions, first one was eluted with washing buffer whereas the others were eluted with $0.08 \mathrm{M}$ and $0.14 \mathrm{M} \mathrm{NaCl}$. RNase activity was eluted mainly with $0.08 \mathrm{M} \mathrm{NaCl}$. Nevertheless, minor peaks of RNase activity were associated with each phosphatase peak (Fig. 6b).

\section{Membrane bound phosphatase}

Activity of phosphatase extracted with $0.5 \%$ Triton X-100 from control plants was too low to be analysed by gel chromatography. Since the activity of membrane bound phosphatase increases in senescing plants (Knypl and Kabzińska 1977; Knypl and Sobolew$\mathrm{ska}$ 1978) older cultures with few yellowing fronds per bottle were taken for analyses. Crude extract hydrolysed NPP most actively at pH 6.0. However, chromatography on Sephadex G-150 revealed the

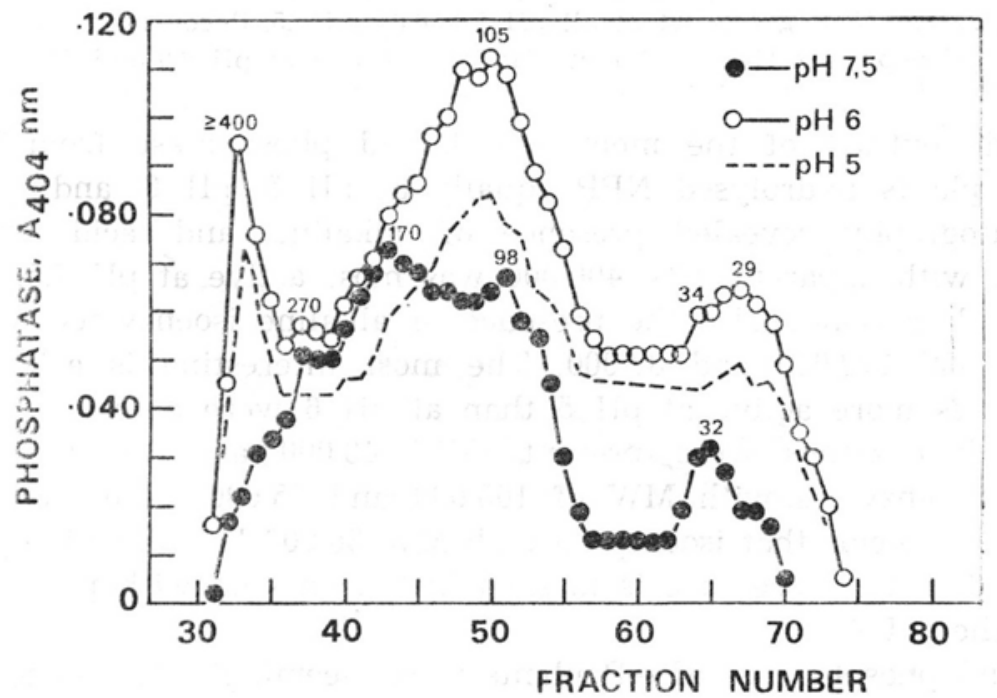

Fig. 7. Elution profile of membrane bound phosphatase of control Spirodela. Enzyme was extracted from 2-week old plants. Activity in crude extract: $0.4 \mathrm{U} \mathrm{g}^{-1}$ fr wt ( $\mathrm{pH}$ 6.0). Recovery from the column of Sephadex G-150: $65 \%$. 
presence of multiple forms of phosphatase in the membrane bound fraction. When the eluates were tested at $\mathrm{pH} \mathrm{6.0,} \mathrm{four} \mathrm{molecular} \mathrm{forms}$ were detected with $M W \supseteq 400000,270000,105000$ and 29000 ; the presence of minor fractions with MW of 34000 and 85000 was manifested by shoulders (Fig. 7). When the eluates were tested at $\mathrm{pH} 7.5$, isoenzymes with MW of $270000,170000,98000$ and 32000 were detected. No phosphatase with optimum activity at $\mathrm{pH}$ 5.0-5.2 was detected.

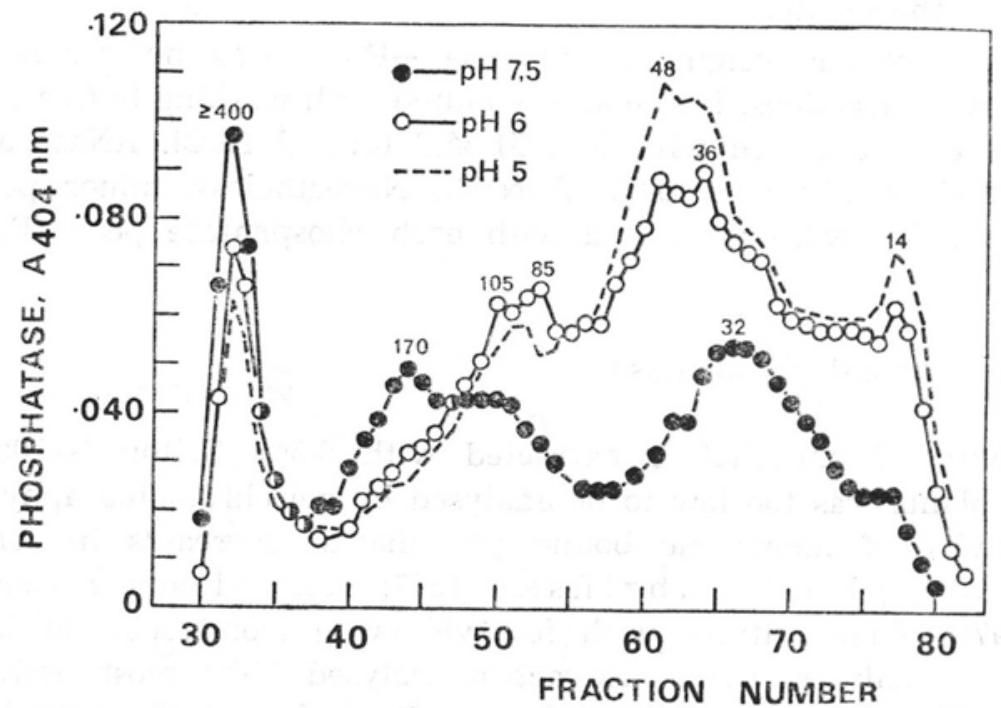

Fig. 8. Elution profile of membrane bound phosphatases of DMMC treated plants. The plants were grown in $0.4 \mathrm{mM}$ DMMC for 9 days. Phosphatase activity in crude extract: $0.45 \mathrm{U} \mathrm{g}^{-1} \mathrm{fr}$ wt at all pH 5.0, 6.0 and 7.5. Recovery from a column of Sephadex G-150: $38 \%$ at $\mathrm{pH} 7.5$, and $56 \%$ at $\mathrm{pH} 6.0$ and 5.0 .

Crude extract of the membrane bound phosphatase from DMMC treated plants hydrolysed NPP equally at $\mathrm{pH} 5, \mathrm{pH} 6$ and $\mathrm{pH}$ 7.5. Chromatography revealed presence of alkaline and acid enzymes. Enzyme with apparent MW 400000 was most active at pH 7.5. Assays at this $\mathrm{pH}$ revealed also the presence of alkaline isoenzymes with apparent MW 170000 and 32000 . The most interesting is a fact that isoenzymes more active at $\mathrm{pH} 5$ than at $\mathrm{pH} 6$ were detected; at least two such enzymes were present (MW 48000 and 14000; Fig. 8). Only two enzymes with MW of 105000 and 85000 were most active at $\mathrm{pH}$ 6. It seems that isoenzyme with $\mathrm{MW} 36000$ has also $\mathrm{pH}$ optimum around 6 , but its presence is masked by an enzyme with $\mathrm{pH}$ optimum below the $\mathrm{pH} 6$.

Bound phosphatases of $-\mathrm{P}$ plants were, seemingly, the same as the soluble ones (Fig. 9). Activity of these alkaline phosphatases was, however, very high in comparison with the control, and they might mask minor quantities of constitutive membrane bound enzymes. 


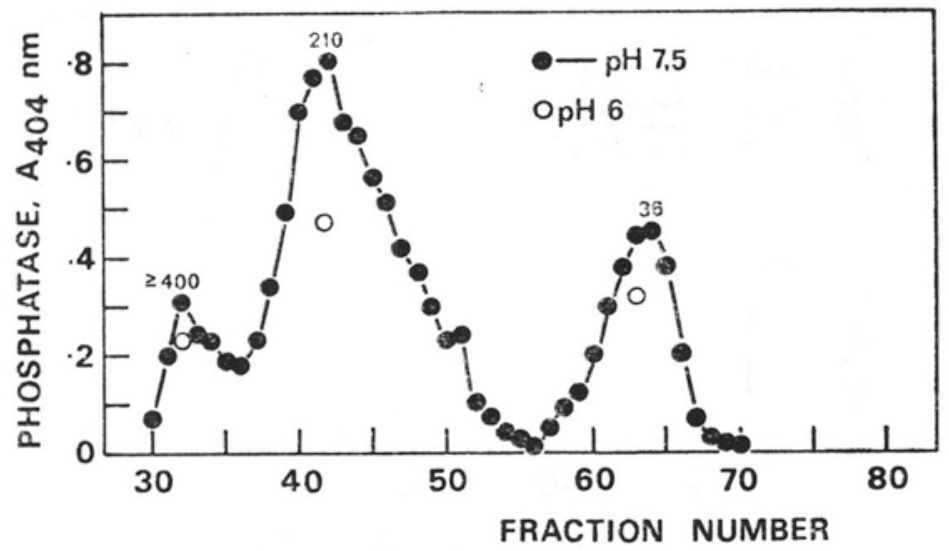

Fig. 9. Elution profile of membrane bound phosphatases of $-\mathrm{P}$ plants. 17-day old -P plants were used for extraction of MB enzymes. In contrast to Fig. 6 and Fig. 7, the enzyme was not precipitated with acetone before application to a column of Sephadex G-150. Enzyme activity is expressed per. $0.25 \mathrm{ml}$ of eluate; recovery: $250 \%$ or original enzyme activity as tested in crude extract.

Extracellular phosphatase

In nutrient medium of senescing control plants phosphatase activity with optimum at $\mathrm{pH} 5.2$ was detected (Fig. 10). At the very time of analyses (25- and 35-days old cultures) there was neither orthophosphate or ammonium in the nutrient media. Plants showed typical symptioms of advanced nitrogen starvation (F e r g u s on and B olla r d 1969). Gel chromatography revealed the presence of extracellular phosphatase with MW 48000 (Fig. 11). Similar enzyme was detected in nutrient medium

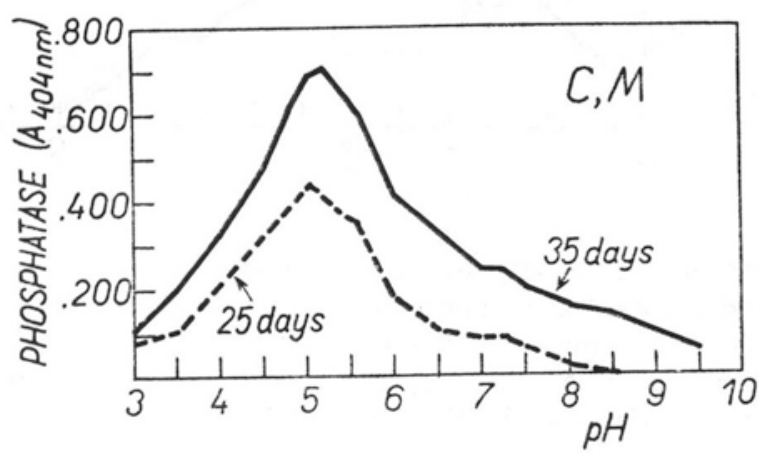

Fig. 10. Effect of $\mathrm{pH}$ on extracellular phosphatase activity in nutrient media of control plants. $0.2 \mathrm{ml}$ aliquots of nutrient media were tested for phosphatase activity at different $\mathrm{pH}$. Enzyme activity expressed as $\Delta \mathrm{A}_{404} \mathrm{~nm}(0.2 \mathrm{ml} \text { medium })^{-1}$ $(20 \mathrm{~min})^{-1}$. At the very time of analyses there was $8.5 \mathrm{~g} \mathrm{fr}$ wt of tissue and $180 \mathrm{ml}$ medium in the case of 25-day old culture, and $13.9 \mathrm{~g} \mathrm{fr}$ wt and $165 \mathrm{ml}$ medium in the case of 35 -days old culture. 


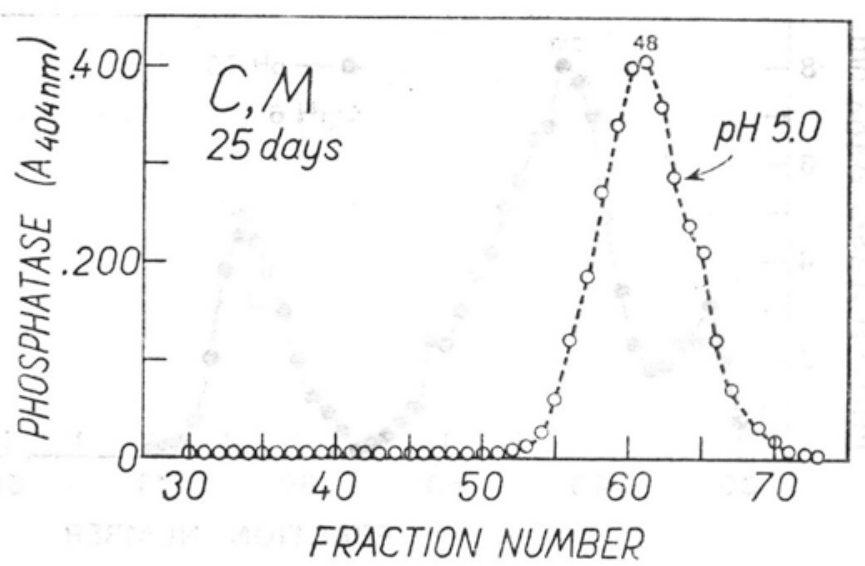

Fig. 11. Elution profile of extracellular phosphatase extracted from nutrient medium of 25-day old control Spirodela. Enzyme activity: $\Delta \mathrm{A}_{404} \mathrm{~nm}(0.5 \mathrm{ml} \text { eluate })^{-1}$ (20 min)-1. Equivalent of $21 \mathrm{ml}$ original medium, corresponding to $1 \mathrm{~g}$ of floating plants, was applied to a column of Sephadex G-150. Recovery: $72 \%$ of applied enzyme activity.

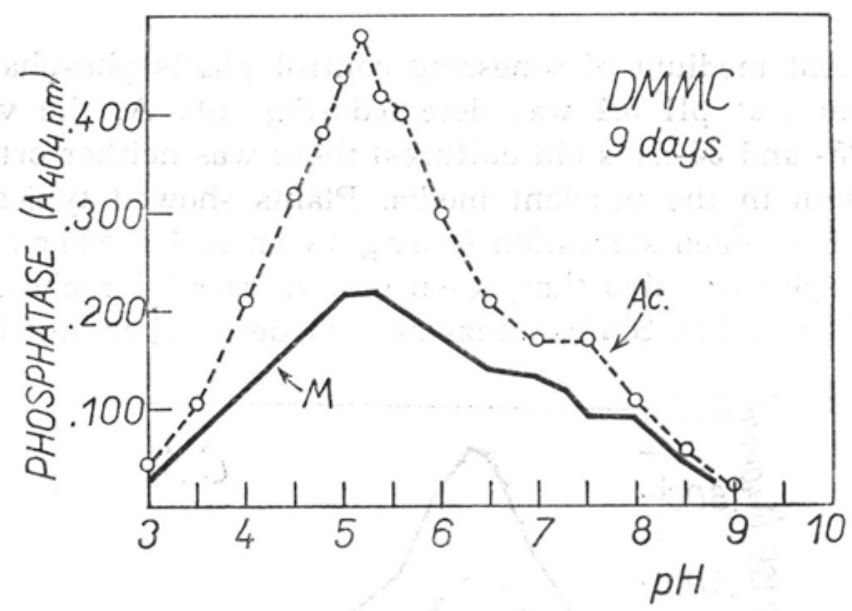

Fig. 12. Effect of $\mathrm{pH}$ on activity of extracellular phosphatase in nutrient medium of DMMC treated plants. $0.1 \mathrm{ml}$ aliquots of crude medium (M) of Spirodela grown for 9 days in the presence of $0.4 \mathrm{mM} \mathrm{DMMC}$, or $0.2 \mathrm{ml}$ aliquots of purified enzyme (Ac.) were tested. At the very time of analyses there were $5 \mathrm{~g} \mathrm{fr}$ wt of tissue and $180 \mathrm{ml}$ of nutrient medium.

of the DMMC treated plants. Both crude medium and purified enzyme hydrolyzed NPP most effectively at pH 5.2 (Fig. 12).

Extracellular phosphatase was not detected in nutrient media of Spirodela in a log phase of growth. Bacteriological tests confirmed sterility of the cultures (cf. Knypland Sobolew ska 1978). 

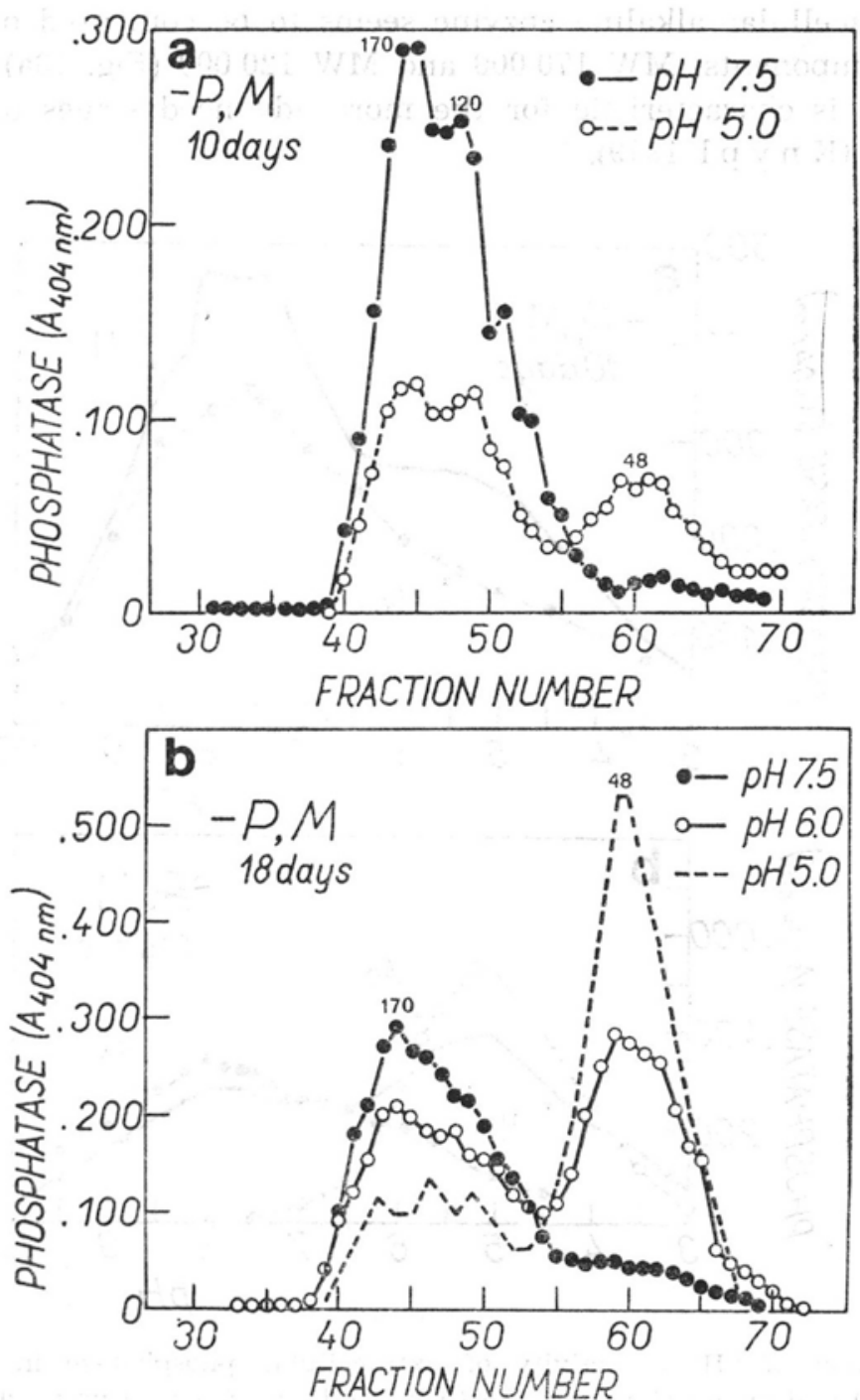

Fig. 13. Elution profile of extracellular phosphatase extracted from nutrient media of 10- and 18-day old phosphate deficient Spirodela. 10-day old plants were dark green, none of the fronds was yellow; yield of $\mathrm{fr}$ wi was $750 \mathrm{mg}$ per $100 \mathrm{ml}$ flask containing $30 \mathrm{ml}$ of nutrient medium. 18-day old plants: young fronds were dark green whereas the old ones turned yellow, roots elongated to $c a .12 \mathrm{~mm}$, much anthocyanins accumulated on the downward side of fronds. Yield was $800 \mathrm{mg}$ fr wt per $100 \mathrm{ml}$ flask. Recovery from the column of Sephadex G-150: 86-96\% of applied enzyme activity.

Two phosphatase fractions were present in nutrient media of $-\mathrm{P}$ plants (Fig. 13): an alkaline one (MW 170000) and an acid one (MW 48000 ). In younger cultures the activity of an alkaline enzyme prevailed over that of the acid one, whereas in older cultures the reverse was 
true. Extracellular alkaline enzyme seems to be composed of two overlapping components: MW 170000 and MW 120000 (Fig. 13a). The lower component is characteristic for the more advanced stages of phosphate deficiency (K n y pl 1979).
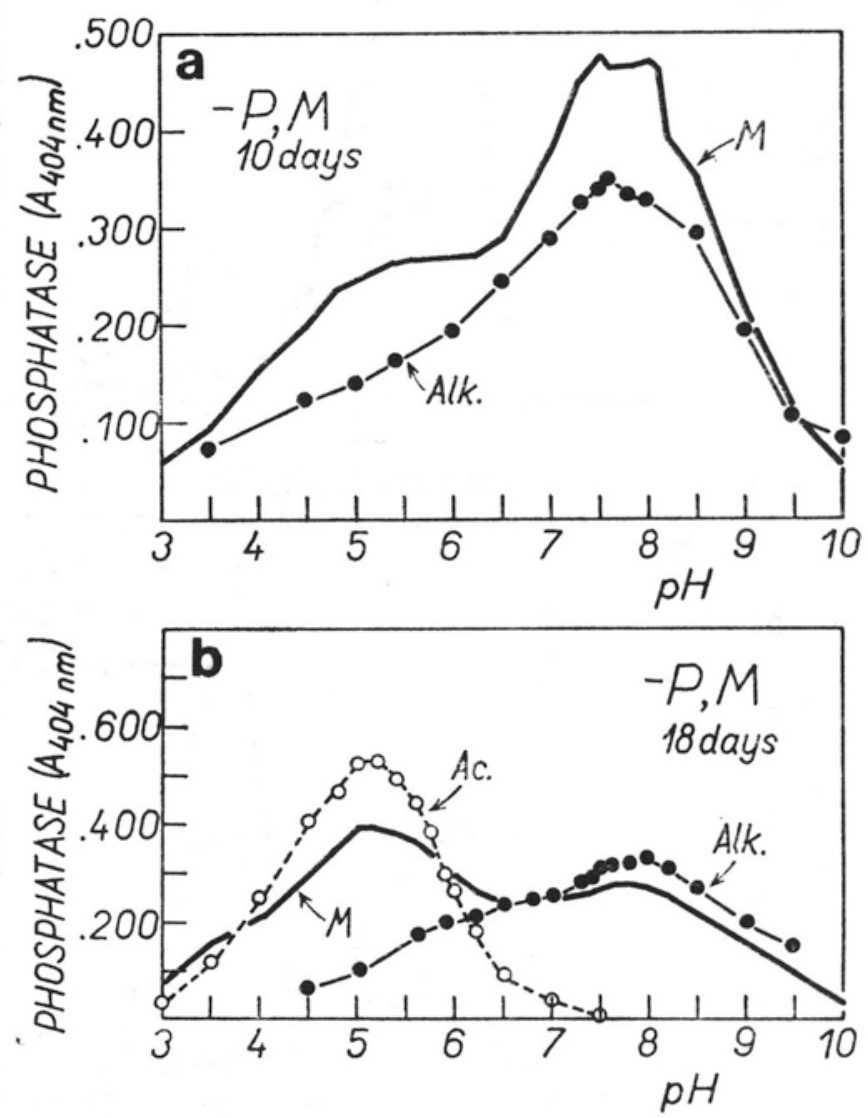

Fig. 14. Effect of $\mathrm{pH}$ on activity of extracellular phosphatase in $-\mathrm{P}$ nutrient medium (M) and on purified alkaline (Alk.) and acid (Ac.) enzymes. $0.2 \mathrm{ml}$ aliquots of crude media or pooled fractions containing alkaline phosphatase (Fig. 13, fractions No. 42-43) or acid phosphatase (Fig. 13, fractions No. 59-60) were assayed. pH of crude media were 7.5 and 7.9 in the case of 10- and 18-day old cultures, respectively.

There were two $\mathrm{pH}$ optima of hydrolysis of NPP by crude -P nutrient media: at $\mathrm{pH} 5.2$ and at $\mathrm{pH}$ 8. The curves representing hydrolysing activity of unpurified media towards NPP as a substrate seem to be simply a result of summed activity of alkaline and acid extracellular enzymes (Fig. 14a). It is of interest that activity of the acid enzyme is sharply dependent on $\mathrm{pH}$. On the contrary, alkaline enzyme is active in a much broader range of $\mathrm{pH}$. This enzyme at $\mathrm{pH} 6$ and $\mathrm{pH} 9$ showed 


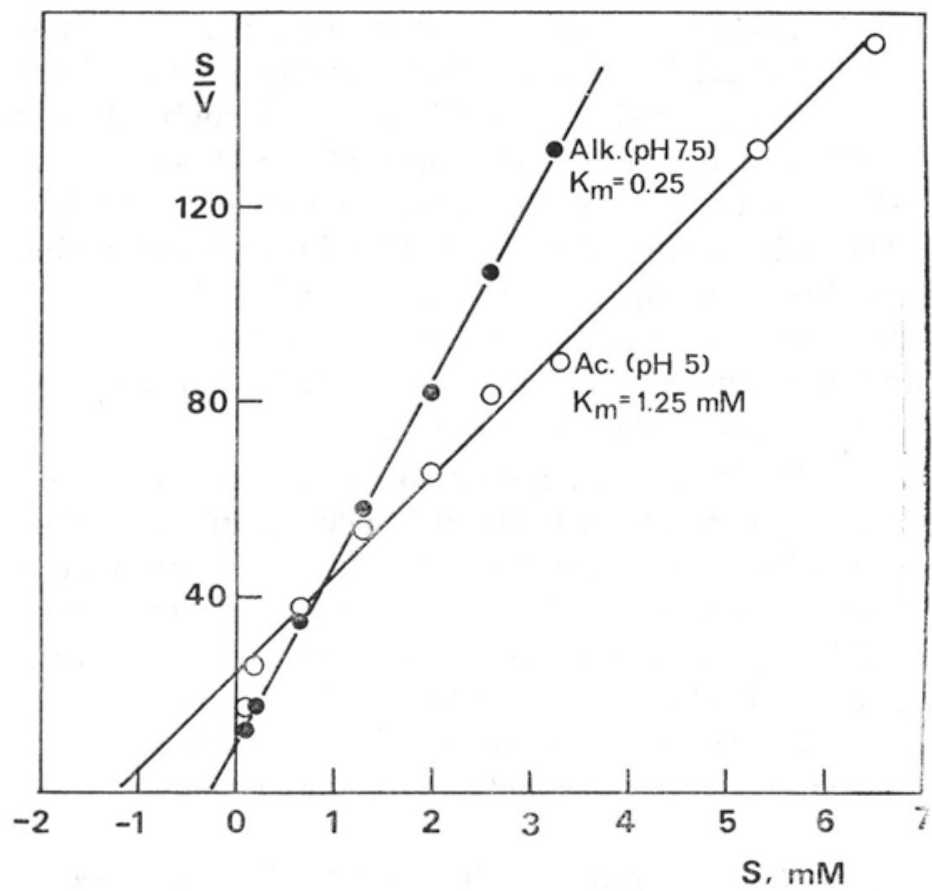

Fig. 15. Determination of $\mathrm{K}_{\mathrm{m}}$ values for alkaline ( $\mathrm{pH}$ 7.5) and acid (pH 5.0) extracellular phosphatases according to Woolf. Source of enzymes: collected fractions No. 43-48 (Alk) and No. 57-63 (Ac) from Fig. 14, 18-day old -P plants.

around $60 \%$ of activity in comparison with $100 \%$ at the optimum $\mathrm{pH} 8$ (Fig. 14b).

The values of $K_{m}$ for acid and alkaline extracellular enzymes were estimated for $1.25 \mathrm{mM}$ and $0.25 \mathrm{mM}$, respectively, when NPP was used as a substrate (Fig. 15).

Senescent control, -P, or DMMC treated plants produced neither extracellular RNase or phosphodiesterase.

\section{DISCUSSION}

This study has shown that soluble phosphatases of control and $-\mathrm{P}$ Spirodela oligorrhiza differ both in $\mathrm{pH}$ optima and apparent molecular weights. The values of mol wt were estimated on a basis of 2-4 separate chromatographic runs. Nevertheless, higher plan phosphatases are giycoproteins (cf. Kruzek and Morawiecka 1978). The same is true for the enzymes of Spirodela; for example, the phosphatase DMMC, S-II contains around $40 \%$ of sugar ( $\mathrm{Kn} \mathrm{y} \mathrm{pl} \mathrm{1978),} \mathrm{and} \mathrm{for} \mathrm{that} \mathrm{reason}$ true values of MW may differ from the values reported in this paper. 
B ieleski (1974) has suggested that high mol wt phosphatase in $-\mathrm{P}$ plants (denoted HI-P) may represent an aggregated form of a low mol wt isoenzyme (denoted LO-P). There is no doubt that constitutive phosphatase CS-I is an oligomeric form of CS-II since both enzymes are eluted from a column of Sephadex G-150 as a single peak (MW around 100000 ) with buffered $0.4 \mathrm{M} \mathrm{NaCl}$ (K n y p l 1978). Heterogeneity of CS-I upon chromatography on DEAE-Sephadex (Fig. 2a) may indicate that this molecular form of the enzyme partially dissociates to CS-II in vitro, and that the enzyme activity eluted with washing buffer is identical with the molecular form CS-II.

Phosphatase CS-II in turn seems to be a product of association of subunits with apparent mol wt $30000-34000$. If this was the case, then phosphatase DMMC,S-II could be regarded as a product of in vivo dissociation of the enzyme CS-II. There are some evidences that dissociation of this type occurs during a course of senescence of this plant (Knypl and Sobolewska 1978). Peak of enzyme activity corresponding to this range of molecular weight was, in fact, detected among membrane bound phosphatases of the senescent control plants (Fig. 7).

DMMC produced a remarkable modification of the pattern of membrane bound phosphatases. The most interesting seems to be a fact that in the presence of DMMC phosphatases with $\mathrm{pH}$ optimum in a range of $\mathrm{pH}$ 5.0-5.2 appeared (Figs 7 and 8). One of these enzymes (MW 48000 ) may be identical with the extracellular acid enzyme. Acid phosphatases have been found to be associated with membranes of chloroplasts, mitochondria and microsomes (M łodzian owski 1972; Hirai and Asahi 1973; Nakano and Asahi 1972), and in Spirodela around $4 \%$ of constitutive acid phosphatase is accessible to external phosphate esters (Bieleski 1974). DMMC at a concentration of 0.4 $\mathrm{mM}$ as applied in this study inhibited growth and chlorophyll accumulation. It could, thus, induce some biochemical events which occur in naturally senescing plants. Marked increase of RNase activity supports a view that this growth retardant at high concentrations might be a factor inducing senescence (cf. Hodge and Sacher 1975). The synthesis of RNase in $-\mathrm{P}$ plants can also be regarded as a symptom of senescence (cf. De Le o and Sacher 1970; Hanson et al. 1965; $\mathrm{Udvardy}$ and Farkas 1972), or as a symptom of stress conditions (cf. B le k hm a n 1977).

Since extracellular acid phosphatase found in nutrient media of senescent control and DMMC treated plants differs from soluble enzymes in $\mathrm{pH}$ optimum and molecular weight, it seems to be excreted by living plants. If it was a product of cell lysis, then other enzymes should be detected in the media of both DMMC treated and $-\mathrm{P}$ plants. Proper analyses revealed, that this was not the case. 
Extracellular alkaline phosphatase released by $-\mathrm{P}$ plants is possibly identical with the membrane bound alkaline enzyme with MW 170000 detected in the control and DMMC-treated plants (Figs. 7 and 8), whereas the acid extracellular enzyme seems to be identical with the MB enzyme (MW 48000 ) detected in the DMMC treated plants (Fig. 8).

It is of interest that $-\mathrm{P}$ plants released, initially, alkaline extracellular phosphatase. This enzyme showed around 5 times higher affinity towards NPP than the acid phosphatase (Fig. 15), and in the presence of both enzymes external phosphate esters could be hydrolyzed in a very broad range of $\mathrm{pH}$ (Fig. 14). The release of an alkaline phosphatase followed by an acid enzyme into the surrounding medium can be regarded as a symptom of adaptation of Spirodela to phosphate deficiency. The enzymes, in natural environment, can possibly release orthophosphate from P-esters otherwise unavailable to this plant (Bieleski 1974; Kny pl 1978b).

Acknowledgments

I thank Dr. Małgorzata Oświęcimska for a sample of DMMC, and to Drs. E. G. Bollard and A. R. Ferguson for original inoculum of Spirodela oligorrhiza. This study was supported by Ministry of Science, High Education and Fechnics under a research project $\mathrm{R}$ 1.9.02.06: Evolution of biological regulatory systems.

\section{REFERENCES}

A mbellan E., Hollander V. P., 1966. Anal. Biochem. 17: 474-484.

Bailey K. M., Phillips I. D. J., Pitt D., 1976. J. exp. Bot. 27: 324-336.

Bieleski R. L., 1974. Roy Soc. New Zealand Bull. 12: 165-170.

B le khman G. I., 1977. Biokhimiya 42: 815-823.

E o 11 a rd E., 1966. Plant and Soil 25: 153-166.

Cox R. M., Thurman D. A., 1978. New Phytologist 80: 17-22.

De L e o P., S a cher J. A., 1970. Plant Physiol. 46: 806-811.

Eisenthal R., Cornish-Bow den A., 1974. Biochem. J. 139: 715-720.

F erguson A. R., B ollard E. G., 1969. Planta (Berl.) 88: 344-352.

F o st e r D. M., W e ber D. J., 1973. Plant Sci. Letters 1: 169-177.

Han s on J. B., W ils on C. M., Chrispee $1 \mathrm{~s}$ M. J., Krueger W. A., S wans o n H. R., 1965. J. exp. Bot. 16: 282-293.

H ewitt E. J., 1958. Encyclopedia of Plant Physiology 4: 427-481.

H ew itt E. J., T a th a m P., 1960. J. exp. Bot. 11: 367-376.

Hirai M., Asahi T., 1973. Plant Cell Physiol. 14: 1019-1029.

Hodge E. T., S a c her J. A., 1975. Biochem. Physiol. Pflanzen 168: 433-441.

Kny pl J. S., 1976a. Biochem. Physiol. Pflanzen 170: 243-252.

Kny p 1 J. S., 1976b. 9th Int. Conf. Plant Growth Substances, Coll. Abstracts of

the Paper Demonstrations. Pilet P. E. (ed.), Lausanne 1976, PD 85, pp. 196-197.

Kny pl J. S., 1977. Biochem. Physiol. Pflanzen 171: 289-298. 
K ny p 1 J. S., 1978a. 12th FEBS Meeting, Abstracts, Dresden 1978. Abstract No. 0223.

Kny p 1 J. S., 1978b. Z. Pflanzenphysiol. 90: 265-277.

Kn y pl J. S., 1979. Bul. Acad. Pol. Sci. Ser. sci. biol., in press.

Knypl J. S., Kabzińsk a E., 1977. Biochem. Physiol. Pflanzen 171: 279-287.

Knypl J. S., Sobolew ska J., 1978. Physiol. Vég. 16: 773-784.

Kn y p l J. S., W i t e k S., Oświęcimska M., 1976. Z. Pflanzenphysiol. 79: 53-61.

K o h 1 J. G., 1969. Flora Abt. A 160: 253-257.

Kruzel M., Morawiecka B., 1978. 12th FEBS Meeting, Abstracts, Dresden 1978. Abstract No. 3737 .

Kubicz A., Wieczorek E., Morawiecka B., 1972. Acta Soc. Bot. Polon. 41: $107-112$.

Lorens-Kubis I., Morawiecka B., Niezgódka M., Hebrowska A., 1975. Acta Soc. Bot. Polon. 44: 255-263.

M c Clure J. W., Alst on R. E., 1966. Amer. J. Bot. 53: 849-860.

Młodzian owski F., 1972. Z. Pflanzenphysiol. 66: 362-365.

Murray D. R., Collier M. D., 1977. Aust. J. Plant Physiol. 4: 843-848.

Nakano M., Asahi T., 1972. Plant Cell Physiol. 13: 101-110.

Papageorgakopoulou N., Georgatsos J. G., 1977. Int. J. Biochem. 8: 611-618.

R e i d M. S., B i el e s ki R. L., 1970a. Planta (Berl.) 94: 273-281.

R e i d M. S., B i e le ski R. L., 1970b. Plant Physiol. 46: 609-613.

Rychter A., Szkutnicka K., Lewak S., 1972. Physiol. Vég. 10: 671-676.

Udwardy J., Farkas G. L., 1972. J. exp. Bot. 23: 914-920.

W illia m s J. T., J u o P.-S., 1976. Biochim. Biophys. Acta 422: 120-126.

Author's address:

Doc. $d r$ hab. J. S. Knypl

Plant Growth Substances Laboratory

University of $€ o ́ d z ́$

Banacha Str. 12/16

PL-90-237 Łódź, Poland

Molekularne formy fosfatazy i rybonukleazy $w$ Spirodela oligorrhiza (Lemnaceae) hodowanej wobec chlorku N,N-dwumetylomorfoliniowego lub przy braku ortofosforanu

\section{Streszczenie}

Techniką chromatografii żelowej (Sephadex G-150) analizowano fosfatazy (EC 3.1.3.2 oraz 3.1.3.1) rozpuszczalne, związane z membranami i ekstracelularne rzęsy wodnej [Spirodela oligorrhiza (Kurz) Hegelm.], hodowanej wobec chlorku N,N-dwumetylomorfoliniowego (DMMC) lub przy braku ortofosforanu (-P). R.ozpuszczalny enzym roślin kontrolnych rozdzielono na dwie frakcje, CS-I i CS-II, charakteryzujące się c.mol. ok. 400000 i 85000 ; obie molekularne formy enzyrnu byly optymalnie aktywne przy pH 6.0. DMMC spowodowal zanik frakcji CS-II i pojawienie się enzymu o c.mol. ok. 34000 . Brak fosforanu powoduje pojawienie się adaptacyjnych enzymów alkalicznych (c.mol. 210000 i 36000 ; optimum pH 7.5).

W roślinach kontrolnych występuje kilka form fosfataz związanych z membranami, przy czym są to enzymy zarówno kwaśne jak i alkaliczne. Pod wpływem DMMC pojawiają się dwie formy molekularne fosfatazy optymalnie aktywne przy 
pH 5 (c.mol. 48000 i 14000), nie wykryte w materiale kontrolnym. Fosfatazy związane $\mathrm{z}$ membranami roślin $-\mathrm{P}$ są identyczne $\mathrm{z}$ fosfatazami rozpuszczalnymi.

Starzejące się rośliny kontrolne oraz rośliny hodowane wobec DMMC wyđzielają fosfatazę kwaśną (optimum pH 5.2; c.mol. 48000 ) do pożywki. Rośliny -P oprócz wymienionej fosfatazy kwaśnej wydzielają również fosfatazę alkaliczrą (optimum $\mathrm{pH}$ 7.8-8.2; c.mol. 170000 ). $\mathrm{K}_{\mathrm{m}}$ extracelularnej fosfatazy kwaśnej i alkalicznej wynosi $1.25 \mathrm{mM}$ i $0.25 \mathrm{mM}$ NPP.

DMMC i brak fosforanu powodują silny wzrost aktywności RNazy (EC 2.7.7.17) o c.mol. 31000 i 28000 .

Sugeruje się, iż spektrum fosfataz w rzęsie wodnej zależy od wieku roślin oraz od dostępności makro- i mikroelementów. 